\title{
Experimental Assessment of the Role of Acetaldehyde in Alcoholic Cardiomyopathy
}

\author{
Nicholas S. Aberle $\mathrm{II}^{1}$ and Jun Ren ${ }^{2 *}$ \\ ${ }^{1}$ Department of Pharmacology, Physiology and Therapeutics, University of North Dakota School of Medicine and Health Sciences. \\ Grand Forks, ND 58203, USA
}

${ }^{2}$ Division of Pharmaceutical Sciences, School of Pharmacy, University of Wyoming College of Health Sciences, Laramie, WY 820713375.

*To whom correspondence should be addressed. Dr. Jun Ren, Associate Professor, Division of Pharmaceutical Sciences, School of Pharmacy, University of Wyoming College of Health Sciences, P. O. Box 3375, Laramie, WY 82071-3375. Tel: (307)-766-6131, Fax: (307)-766-2953, E-mail: jren@uwyo.edu.

Submitted: September 3, 2002; Revised: November 27, 2002; Accepted: December 12, 2002; Published: February 17, 2003

Indexing terms: Heart, Transgenic, Myocyte, Acetaldehyde (ACA), Alcohol, Excitation-Contraction (E-C) coupling.

\section{ABSTRACT}

Alcoholism is one of the major causes of non-ischemic heart damage. The myopathic state of the heart due to alcohol consumption, namely alcoholic cardiomyopathy, is manifested by cardiac hypertrophy, compromised ventricular contractility and cardiac output. Several mechanisms have been postulated for alcoholic cardiomyopathy including oxidative damage, accumulation of triglycerides, altered fatty acid extraction, decreased myofilament $\mathrm{Ca}^{2+}$ sensitivity, and impaired protein synthesis. Despite intensive efforts to unveil the mechanism and ultimate toxin responsible for alcohol-induced cardiac toxicity, neither has been clarified thus far. Primary candidates for the specific toxins are ethanol, its first and major metabolic product - acetaldehyde (ACA) and fatty acid ethyl esters. Evidence from our lab suggests that ACA directly impairs cardiac function and promotes lipid peroxidation resulting in oxidative damage. The ACA-induced cardiac contractile depression may be reconciled with inhibitors of Cytochrome P450 oxidase, xanthine oxidase and lipid peroxidation Unfortunately, the common methods to investigate the toxicity of ACA have been hampered by the fact that direct intake of ACA is toxic and unsuitable for chronic study, which is unable to provide direct evidence of direct cardiac toxicity for ACA. In order to overcome this obstacle associated with the chemical properties of ACA, our laboratory has used the chronic ethanol feeding model in transgenic mice with cardiac over-expression of alcohol dehydrogenase (ADH) and an in vitro ventricular myocyte culture model. The combination of both in vivo and in vitro approaches allows us to evaluate the role of ACA in ethanol-induced cardiac toxicity and certain cellular signaling pathways leading to alcoholic cardiomyopathy.

\section{INTRODUCTION}

Chronic alcoholism has been demonstrated to cause detrimental damage to cardiac muscles leading to the development of alcoholic cardiomyopathy which accounts for $\sim 33 \%$ of all dilated cardiomyopathies (1). In patients with chronic alcoholism, the occurrence of cardiomyopathy of any kind, is increased to $50 \%$, with a majority of these patients dying from heart failure. Alcoholic cardiomyopathy is manifested as cardiomegaly, disrupted myofibrillary architecture, reduced myocardial contractility, decreased ejection volumes and enhanced risk of stroke and hypertension $(2,3)$. Clinical studies have demonstrated that abstinence from alcohol prior to a certain stage may reverse this specific type of cardiomyopathy (3). There have been several hypotheses formulated regarding the pathogenesis of alcoholic cardiomyopathy, including direct and indirect cardiotoxicity of alcohol (4), accumulation of fatty acid ethyl esters (5), and the cardiac toxicity from the first oxidized metabolic product of ethanol, namely acetaldehyde (ACA) $(6,7,8,9)$. Nevertheless, none of these hypotheses have received convincing experimental support necessary to be fully validated.

ACA, the first oxidized metabolic product of ethanol, has been considered a likelihood candidate toxin for the pathogenesis of alcoholic cardiomyopathy because its ability to concentrate in the heart and its high reactive property compared to ethanol (6). Our laboratory has shown that ACA may directly impair

(C) 2003. Biological Procedures Online. Published in Biological Procedures Online under license from the author(s). Copying, printing, redistribution and storage permitted. 
cardiac excitation-contraction (E-C) coupling and inhibit sarco(endo)plasmic reticulum (SR) $\mathrm{Ca}^{2+}$ release function (7, 8, $9,10)$. However, the advancement of the ACA toxicity theory has been stalled due to the lack of suitable models to experimentally alter blood ACA and the technical constraints of ACA manipulation such as low boiling point and high chemical reactivity. These properties of ACA are likely to impose certain experimental and technical difficulties because of the ability of ACA to readily escape from solution or test chambers, and may cause an inaccuracy in the concentration of ACA, which would bias the experimental findings. Normally, ACA degrades very quickly $(\sim 5$ times that of ethanol) via aldehyde dehydrogenase (ALDH) which maintains ACA at a low blood level $(<0.5 \mu \mathrm{M})$ following ingestion of $0.5 \mathrm{~g} / \mathrm{kg}$ ethanol. Higher ACA levels $(\sim 2 \mu \mathrm{M})$ may be seen in alcoholics when given the same dose of ethanol, probably due to hepatic inhibition of ALDH activity (11). Furthermore, blood ACA levels may reach $30-500 \mu \mathrm{M}$ following ethanol intoxication in certain populations such as Asians and African American who carry a mutated ALDH with low $K_{m}$ (12), making them theoretically ideal to examine the role of ACA. However, the intolerance of these individuals to ethanol ingestion makes it practically impossible to conduct this analysis. Earlier experiments that employed metabolic inhibitors to alter ACA levels (e.g., the ALDH inhibitor cyanamide) revealed the inhibitors to be nonspecific, ineffective, toxic and difficult to maintain in experimental animals (13). Due to the lack of a suitable model or method to assess the chronic effects of ACA, our group recently developed a novel transgenic mouse and a cardiac myocyte culture model to investigate the chronic effects of ACA on the heart, both in vivo and in vitro.

Study of ventricular function provides the most direct evidence of cardiac contractile function during drug intervention or certain pathological conditions. Over the past decades, a plethora of new techniques have been established to evaluate the ventricular function at different levels (from echocardiography to single myocyte contraction). The method discussed here is a video-based edge-detection technique with simultaneous measurement of intracellular $\mathrm{Ca}^{2+}$ homeostasis in isolated ventricular myocytes.

\section{MATERIALS AND METHODS}

\section{Experimental Animal Models}

\section{Experimental Animals and Chronic Ethanol Ingestion}

Adult Sprague-Dawley or Wistar rats are obtained as pairs of littermates weighing approximately $50 \mathrm{~g}$ and are usually used as described (14). All animals are housed in a temperaturecontrolled room under a 12-h light/12-h dark illumination cycle and allowed tap water ad libitum. Animals are initially maintained on standard rat chow for a one-week quarantine period. Following the quarantine period, all animals are then introduced to a nutritionally complete liquid diet (Shake \& Pour Bioserv Inc., Frenchtown, NJ, USA) for a one-week acclimation period (15). The use of a liquid diet is based on the observations made by Keane and Leonard (16) that ethanol self-administration resulted in less nutritional deficiencies and less stress to the animals in comparison to forced-feeding regimens, intravenous administration, or aerosolized inhalation. Upon completion of the acclimation period, one littermate is maintained on the liquid diet without ethanol, and the remaining littermates begin a 7-day period of ethanol introduction. Ethanol-consuming animals are given a diet containing $12 \%, 24 \%$, and $36 \%$ of isocaloric ethanol on days $1-4,5-7$ and 8 , respectively. An isocaloric (250 cal/liter) pairfeeding regimen is employed to eliminate the possibility of nutritional deficits. Control animals, which are randomly paired with the ethanol-consuming animals prior to the start of feeding, are provided with the equal volume of liquid diet the paired ethanol-consuming animals drank the day before. The chronic feeding usually lasts between $8-12$ weeks. Blood pressure and body weight are monitored with a semiautomated, amplified tail-cuff device (IITC Inc., Woodland Hills, CA) and a standard laboratory scale. The serum ethanol concentration is determined using a biochemistry analyzer (YSI 2700 Biochemistry Analyzer, Yellow Springs, OH).

\section{Transgenic Models}

To determine if enhanced/reduced cardiac exposure to ACA exacerbates/alleviates cardiac damage following chronic ingestion of alcohol, alcohol metabolism may be artificially altered in two different lines of transgenic mice to either increase or decrease cardiac exposure to ACA. The first transgene is to increase the expression of alcohol dehydrogenase (ADH) specifically in the heart. Increased ADH activity has been shown to result in greater alcohol metabolism and cardiac production of ACA following alcohol ingestion $(20,21)$. Our preliminary evidence demonstrates that these mice are markedly more sensitive than control animals to chronic alcohol-induced cardiac function as well as morphological damage $(20,21)$. These results indicate that chronic exposure to ACA, even at low levels, may be cardiotoxic. The results are consistent with the hypothesis that ACA contributes to the pathogenesis of alcoholic cardiomyopathy. The second transgene is to increase aldehyde dehydrogenase (ALDH) in the liver or non-specifically in the body. The liver is the prime organ for alcohol metabolism and breakdown of ACA into acetate via ALDH enzyme. Overexpression of ALDH should greatly speed up the breakdown of ACA, and decrease the total body burden of ACA, resulting in markedly reduced cardiac exposure to ACA following alcohol ingestion. ADH transgene has been constructed to produce local over-expression of ADH in the heart (20). This gene includes the mouse $\alpha$-myosin heavy chain (MHC) promoter to drive cardiac specific expression. The 
cDNA for murine class I ADH (17) is inserted downstream from the promoter. This cDNA is chosen because class I ADH is the most efficient in the oxidation of ethanol. Wild-type mice (FVB strain) obtained from the in house colony are used to produce transgenic lines containing the ADH transgene (18). The transgenic animals are produced using standard procedures. For producing the ALDH transgenic mice, the insert will be excised and separated from the plasmid by $\mathrm{KpnI} /$ NotI restriction digestion and agarose gel electrophoresis. Prior to injection the insert will be purified on Qiagen 20 columns, followed by spin gel chromatography and filtration through $0.22 \mu \mathrm{m}$ filters. Approximately 100 copies of the purified transgene insert will be microinjected into each mouse embryo of the inbred strain FVB. Twenty microinjected embryos will be implanted into each pseudopregnant female and allowed to come to term. Once transgenic founders are identified they will maintained be on the FVB background. As a means of readily identifying transgenic mice, a second, marker transgene is coinjected with the ADH or ALDH transgenes into fertile embryos. The marker transgene expresses the tyrosinase gene in melanocytes of transgenic mice (19). This transgene corrects albinism since albino mice carry a point mutation in their endogenous tyrosinase gene. As FVB mice are albino this system is suitable for our transgenic animals. The advantages of this identification method are that transgenic mice can be recognized at birth by their pigmentation (20), most mice are spared from the trauma of tail clipping and an enormous amount of routine labor is saved. Southern blot analysis may still be required on DNA from the first generation of founder mice to determine copy number and to insure that the transgenes are intact. Considering the inevitable experimental and technical difficulties of administering ACA in vivo, these transgenic models should provide valid tools to assess the role of ACA in body function.

\section{Assessment of the ACA Production After Ethanol Challenge}

Cardiac tissues or ventricular myocytes $(200,000$ cells per ml) isolated from control or experimental animals with or without acute (30 min after $0.4 \mathrm{~g} / \mathrm{kg}$ injection of ethanol) or chronic ethanol challenge are placed immediately in sealed vials and stored at $-80^{\circ} \mathrm{C}$ until analysis. Immediately before analysis, the samples are warmed to $25^{\circ} \mathrm{C} .2 \mathrm{ml}$ of the headspace gas from each vial is removed through the septum on the cap with a gas tight syringe and transferred to a $200 \mu \mathrm{l}$ loop injection system on a Hewlett-Packard 5890 gas chromatograph equipped with a flame ionization detector. ACA and other components are separated on a 9-meter VOCOL capillary column (Supelco, Inc.) with a $1.8 \mu \mathrm{m}$ film thickness and an inner diameter of $0.32 \mathrm{~mm}$. The temperature is held isothermally at $30^{\circ} \mathrm{C}$, and helium is used as the carrier gas at a flow rate of $1.8 \mathrm{ml} / \mathrm{min}$. Under the specified conditions, separation of ACA from ethanol and other compounds is usually complete within one minute. Quantification may be achieved by calibrating the Gas
Chromatography peak areas against those from headspace samples of known ACA standards, over a similar concentration range as the cell or tissue samples, in the same buffer (21).

\section{Cell Culture Model}

\section{Isolation of Ventricular Myocytes}

Single ventricular myocytes are isolated as described previously (21). In brief, animals are sacrificed after being anesthetized with a ketamine/xylazine solution (3:1, $1.32 \mathrm{mg} / \mathrm{kg}$, i.p.) and hearts are rapidly removed and perfused (at $37^{\circ} \mathrm{C}$ ) with oxygenated $\left(5 \% \mathrm{CO}_{2}-95 \% \mathrm{O}_{2}\right)$ Krebs-Henseleit bicarbonate (KHB) buffer (mM: $\mathrm{NaCl} 118, \mathrm{KCl} 4.7, \mathrm{CaCl}_{2} 1.25, \mathrm{MgSO}_{4} 1.2$, $\mathrm{KH}_{2} \mathrm{PO}_{4}$ 1.2, $\mathrm{NaHCO}_{3}$ 25, N-[2-hydro-ethyl]-piperazine-N'-[2ethanesulfonic acid] (HEPES) 10, glucose 11.1, pH 7.4. Hearts are subsequently perfused with a nominally $\mathrm{Ca}^{2+}$-free KHB buffer for 2-3 min until spontaneous contractions ceased followed by a 20 min perfusion with $\mathrm{Ca}^{2+}$-free $\mathrm{KHB}$ containing $223 \mathrm{U} / \mathrm{ml}$ collagenase (Worthington Biochemical Corp., Freehold, NJ) and $0.1 \mathrm{mg} / \mathrm{ml}$ hyaluronidase (Sigma Chemical, St. Louis, MO). After perfusion, the left ventricle is removed, minced and incubated with the fresh enzyme solution $\left(\mathrm{Ca}^{2+}\right.$-free KHB containing 223 $\mathrm{U} / \mathrm{ml}$ collagenase) for 3-5 min. The cells are further digested with $0.02 \mathrm{mg} / \mathrm{ml}$ trypsin (Sigma) before being filtered through a nylon mesh $(300 \mu \mathrm{m})$ and collected by centrifugation $(60 \mathrm{x}$ g for 60 $\mathrm{sec})$. Myocytes are then resuspended in a sterile-filtered, $\mathrm{Ca}^{2+}$ free KHB buffer containing (in $\mathrm{mM}$ ): $\mathrm{NaCl} 131, \mathrm{KCl} 4, \mathrm{MgCl}_{2} 1$, HEPES 10 , and glucose 10 , supplemented with $2 \%$ bovine serum albumin (BSA), with a $\mathrm{pH}$ of 7.4 at $37^{\circ} \mathrm{C}$. Initially, cells are washed with $\mathrm{Ca}^{2+}$-free KHB buffer in order to remove any remnant enzyme and extracellular $\mathrm{Ca}^{2+}$ is added incrementally back to $1.25 \mathrm{mM}$.

\section{Culture of Myocytes with Specific Pharmacological Interventions}

Isolated ventricular myocytes from adult normal Sprague-Dawley or Wistar rats maintained in a defined medium consisting of Medium 199 (Sigma) with Earle's salts containing HEPES (25 $\mathrm{mM})$ and $\mathrm{NaHCO}_{3}(25 \mathrm{mM})$, supplemented with albumin (2 $\mathrm{mg} / \mathrm{ml})$, L-carnitine $(2 \mathrm{mM})$, creatine $(5 \mathrm{mM})$, taurine $(5 \mathrm{mM})$, insulin $(100 \mathrm{nM})$, penicillin $(100 \mathrm{U} / \mathrm{ml})$, streptomycin $(100$ $\mu \mathrm{g} / \mathrm{ml})$, and gentamicin $(5 \mu \mathrm{g} / \mathrm{ml})(22)$. The modified culture medium is composed of the following per $500 \mathrm{ml}$ Medium 199 buffer: $1.0 \mathrm{~g}$ bovine albumin (Sigma), $0.2 \mathrm{~g} \mathrm{~L}$-carnitine (Sigma), $0.33 \mathrm{~g}$ creatine (Sigma), $0.31 \mathrm{~g}$ taurine (Sigma), $500 \mathrm{mg}$ penicillin/streptomycin (Gibco), $2.5 \mathrm{mg}$ gentamycin (Sigma), and $1.0 \mathrm{ml}\left(10^{-7} \mathrm{M}\right)$ insulin. Myocytes are normally cultured in $2 \mathrm{ml}$ medium in sealed vials with silicone septa (VWR product number 15900-008) for $4-6$ hours with ACA $(\mu \mathrm{M}$ or $\mathrm{mM}$ ranges) or specific pharmacological intervention before mechanical and intracellular $\mathrm{Ca}^{2+}$ properties are evaluated. Our earlier studies failed to observe any noticeable mechanical effect from ACA at concentration below low $\mathrm{mM}$ range in either 
cardiac tissues or myocytes $(7,10)$, which may be due to the volatile property of ACA in open air. In some studies, the myocytes are co-incubated with the lipid peroxidation inhibitor, butylated hydroxytoluene $(20 \mu \mathrm{M})$, the CYP2E1 inhibitor diallyl sulfide $(100 \mu \mathrm{M})$, the xanthine oxidase inhibitor allopurinol (100 $\mu \mathrm{M})$ or the aldehyde oxidase inhibitors menadione $(50-100$ $\mu \mathrm{M})$ and chlorpromazine $(100 \mu \mathrm{M})$. The cells are maintained at $37^{\circ} \mathrm{C}$ in an incubator with $100 \%$ humidity and $5 \% \mathrm{CO}_{2}$. Mechanical properties have been shown to remain relatively stable in myocytes within $12-24 \mathrm{hr}$ in the serum-free medium. Only rod-shaped myocytes with clear edges are selected for recording of mechanical properties or intracellular $\mathrm{Ca}^{2+}$ transients. Our preliminary data revealed that ACA at $\mu \mathrm{M}$ range depresses myocyte contractile function possibly through ethanolinducible form of cytochrome P-450 oxidase (CYP2E1), xanthine oxidase and lipid peroxidation (23).

\section{Mechanical and Functional Characterization}

\section{Cell Shortening/Relengthening Measurements}

Mechanical properties of ventricular myocytes are assessed using an IonOptix MyoCam ${ }^{\circledR}$ video-based system (IonOptix Co., Milton, MA) as described (24). In brief, coverslips with cells attached are placed in a chamber mounted on the stage of an inverted microscope (IX-70) and superfused $(\sim 2 \mathrm{ml} / \mathrm{min}$ at $25^{\circ} \mathrm{C}$ ) with a buffer containing (in $\mathrm{mM}$ ): $\mathrm{NaCl} \mathrm{131,} \mathrm{KCl} 4$, $\mathrm{CaCl}_{2} 1, \mathrm{MgCl}_{2}$ 1, glucose 10, HEPES 10, at $\mathrm{pH}$ 7.4. The cells are field-stimulated at a frequency of $0.5 \mathrm{~Hz}, 3 \mathrm{msec}$ in duration. A video-based edge-detector is used to capture and convert changes in cell length during shortening and relengthening into an analogue voltage signal. Cell shortening and relengthening are assessed using the following indices: peak shortening (PS), time-to-90\% PS (TPS) and time-to- $90 \%$ relengthening $\left(\mathrm{TR}_{90}\right)$, maximal velocities of shortening $(+\mathrm{dL} / \mathrm{dt})$ and relengthening $(-\mathrm{dL} / \mathrm{dt})$, respectively.

\section{Intracellular $\mathrm{Ca}^{2+}$ Transient Measurement}

Myocytes are loaded with fura-2/AM $(0.5 \mu \mathrm{M})$ for $10 \mathrm{~min}$ at $25^{\circ} \mathrm{C}$. Fluorescence measurements are recorded with a dualexcitation single-emission fluorescence photomultiplier system (IonOptix). Myocytes are placed on an inverted microscope and imaged through an Olympus Fluor 40x oil objective. Myocytes are exposed to light emitted by a $75 \mathrm{~W}$ halogen lamp through either a 360 or $380 \mathrm{~nm}$ filter while being stimulated to contract at $0.5 \mathrm{~Hz}$. Fluorescence emissions are detected between $480-520 \mathrm{~nm}$ by a photomultiplier tube after initial illumination at $360 \mathrm{~nm}$ for $0.5 \mathrm{sec}$ and then at $380 \mathrm{~nm}$ for the duration of the recording protocol. The $360 \mathrm{~nm}$ excitation scan is repeated at the end of the protocol and qualitative changes in intracellular $\mathrm{Ca}^{2+}$ concentration $\left(\left[\mathrm{Ca}^{2+}\right] \mathrm{i}\right)$ is inferred from the ratio of the fura-fluorescence intensity (FFI) at both wavelengths. Fluorescence decay time $(\tau)$ is also measured as an indication of the intracellular $\mathrm{Ca}^{2+}$ clearing rate (24).

\section{Evaluation of the Function of Sarco(endo)plasmic Reticulum $\mathrm{Ca}^{2+}$-ATPase (SERCA)}

In order to assess the SERCA-mediated cytosolic $\mathrm{Ca}^{2+}$ clearing, the previously described protocol (25) is followed. After steady-state myocyte contraction had been established, sarcoplasmic reticulum (SR) release is initiated by a brief (100 $\mathrm{ms})$ and rapid introduction of caffeine $(10 \mathrm{mM})$. The introduction of caffeine is under a $\mathrm{Na}^{+}$- and $\mathrm{Ca}^{2+}$-free solution $\left(0 \mathrm{Na}^{+} / 0 \mathrm{Ca}^{2+}\right)$. This maneuver should prevent the extrusion of $\mathrm{Ca}^{2+}$ through $\mathrm{Na}^{+}-\mathrm{Ca}^{2+}$ exchanger (NCX). The parameters by which SR function is assessed are $\mathrm{SR} \mathrm{Ca}^{2+}$ release (measured by area of cell shortening phase normalized to peak shortening amplitude, $\mathrm{A}_{S} / \mathrm{PS}$ ) and $\mathrm{SR} \mathrm{Ca}^{2+}$ uptake (area of cell relengthening phase normalized to peak shortening amplitude $\left.\mathrm{A}_{\mathrm{R}} / \mathrm{PS}\right)$.

\section{Evaluation of $\mathrm{Na}^{+} / \mathrm{Ca}^{2+}$ Exchanger (NCX) Function}

To evaluate the function of NCX in cardiomyocytes, the myocytes are exposed myocytes to a long caffeine protocol. Throughout the continuous caffeine application, SR $\mathrm{Ca}^{2+}$ uptake is functionally disabled since caffeine prevents $\mathrm{SR} \mathrm{Ca}^{2+}$ accumulation $(25,26)$. Therefore, the intracellular $\mathrm{Ca}^{2+}$ transient decline primarily depends on NCX and slow processes such as mitochondrial $\mathrm{Ca}^{2+}$ uptake and sarcolemmal (SL) $\mathrm{Ca}^{2+}$ ATPase (27), in the presence of extracellular $\mathrm{Na}^{+}$and $\mathrm{Ca}^{2+}$ (control buffer with $10 \mathrm{mM}$ caffeine). After the repeated long caffeine exposure (after re-establishing steady-state contraction), in the presence of $5 \mathrm{mM} \mathrm{Ni}^{2+}$ blocks the extrusion of $\mathrm{Ca}^{2+}$ through NCX. Under these conditions, cytosolic $\mathrm{Ca}^{2+}$ clearance primarily depends on the slow processes. The quantification NCX-dependent $\mathrm{Ca}^{2+}$ clearance is measured as differences between areas underneath the twitch curve (normalized to peak shortening amplitude) before and after application of $\mathrm{Ni}^{2+}$.

\section{Biochemical Evaluations of Cardiac Damage}

\section{Preparation of Mitochondrial Fraction}

Myocardial tissue specimens (70 to $80 \mathrm{mg}$ ) are minced and homogenized at $4^{\circ} \mathrm{C}$ for $30 \mathrm{sec}$ in 12 volumes of HES buffer, which consisted of $10 \mathrm{mM}$ HEPES-NaOH (pH 7.4), $1 \mathrm{mM}$ EDTA, and $250 \mathrm{mM}$ sucrose, in a glass homogenizer with a Teflon pestle. The homogenate produced is then centrifuged at $4^{\circ} \mathrm{C}$ and $700 \mathrm{~g}$ for 10 minutes in order to remove any nuclear and myofibrillar debris, the resultant supernatant is centrifuged at $7000 \mathrm{~g}$ for 10 minutes. The pellet is resuspended and washed 3 times with HES buffer (28). 


\section{Measurement of Mitochondrial Respiration}

Mitochondrial respiration is measured using an oxygen electrode (YSI International) and oxygen consumption chamber (Gibson Medical Electronics). Experiments are performed at $37^{\circ} \mathrm{C}$. The assay medium contained $125 \mathrm{mM} \mathrm{KCl}$, $5 \mathrm{mM} \mathrm{MgCl}_{2}, 2 \mathrm{mM} \mathrm{KPO}_{4}$ amd $5 \mathrm{mM}$ HEPES-KOH (pH 7.4). Mitochondria are diluted to $0.1 \mathrm{mg} / \mathrm{ml}$. Complex I linked (5 $\mathrm{mM}$ glutamate) and complex II-linked substrates (5 mM succinate with $1 \mu \mathrm{g} / \mathrm{ml}$ rotenone) are use for investigations. State 3 respiration is measured for 2 min following the addition of ADP $(1 \mathrm{mM})$. The individual respiratory complexes (I-V) are measured as described previously $(29,30)$.

\section{Oxidative Stress Status - Glutathione Assay}

Glutathione levels are determined in cardiac cells and tissues as an indication of oxidative stress. Glutathione peroxidase catalyzes the reduction of lipid hydroperoxides or hydrogen peroxide using reduced glutathione (GSH) as substrate, thus providing a line of protection against oxidative stress and lipid peroxidation. GSH is regenerated by the reduction of glutathione disulfide (GSSG) through the catalytic action of glutathione reductase. A low ratio of GSH/GSSG suggests enhanced oxidative stress. GSH and GSSG levels are measured according to the method described by Griffith (31). Tissues are washed with PBS buffer and $5 \mathrm{mM}$ EDTA. For measurement of GSH, frozen tissue samples are homogenized in 4 volumes $(\mathrm{w} / \mathrm{v})$ of $1 \%$ picric acid. Acid homogenates are centrifuged at $16,000 \times \mathrm{g}$ (30 minutes) and supernatant fractions collected. Supernatant fractions are assayed for total GSH and GSSG by the standard recycling method (31) and GSH content is determined using a standard curve generated from known concentrations of GSH. The procedure consisted of using onehalf of each sample for GSSG determination and the other half for GSH. Samples for GSSG determination are incubated at room temperature with $2 \mu \mathrm{l}$ of 4-vinyl pyridine (4-VP) per 100 $\mu 1$ sample for 1 hour after vigorous vortexing. Incubation with 4-VP conjugates any GSH present in the sample so that only GSSG is recycled to GSH in the recycling assay. This allowed for measurement of only GSSG without interference by GSH. The GSSG (as GSHx2) is then subtracted from the total GSH to determine actual GSH level.

\section{Fluorescent Detection of Reactive Oxygen Species}

$2^{\prime}, 7^{\prime}$-Dichlorofluorescein (DCF) can be used as a measure of the oxidative stress in myocyte (32). DCF diacetate (DCFDA) will be added to cells of interest for $30 \mathrm{~min}$. DCFDA is prepared in ethanol and diluted into myocyte culture medium to a final concentration of $5 \mathrm{mM}$. DCFDA is taken up by cells and on deacetylation forms a nonfluorescent DCF. Upon oxidation, this becomes DCF. Myocytes are trypsinized but not fixed, and the mean fluorescence is measured for 10,000 cells using a Becton Dickinson FACScan with excitation at $488 \mathrm{~nm}$ and emission at $530 \mathrm{~nm}( \pm 21 \mathrm{~nm})$.

\section{Lipid Peroxidation}

In order to assess lipid peroxidation, malondialdehyde (MDA) and 4-Hydroxy-2-nonenal (4-HNE) levels, end products of lipid peroxidation, are measured in the cells from in vivo and in vitro studies. A colorimetric assay (LPO-586 Kit; Oxis International) that is based on the method of Esterbauer et al. (33) is used to determine levels of lipid peroxidation. The protein concentration is determined using the Bradford method. Protein samples are stored at $-70^{\circ} \mathrm{C}$ until analysis. In $200 \mu \mathrm{l}$ of sample, $10 \mu 1$ of $0.5 \mathrm{M}$ BHT and $650 \mu 1$ of Reagent 1 is added. The tubes are vortexed and $150 \mu 1$ of $15.4 \mathrm{M}$ methanesulfonic acid (Reagent 2) is added to the tubes. Samples are then incubated at $45^{\circ} \mathrm{C}$ for $45 \mathrm{~min}$, which is followed by centrifugation for $10 \mathrm{~min}$ at $15,000 \mathrm{x} \mathrm{g}$. The resultant clear supernatant is transferred to a cuvette and the absorbance is measured at $586 \mathrm{~nm}$ (color is stable for 1 hour at room temperature). Each assay that is performed also included sample blanks, reagent blanks and MDA and 4-HNE standards. The analyte concentration in each sample is calculated using the molar extinction coefficient at $586 \mathrm{~nm}$ of 110,000 .

\section{Protein Carbonyl Assay}

To assess the oxidative protein damage specific to the heart, the carbonyl content of protein extracted from mitochondria and used for analysis (34). Briefly, proteins are extracted and lysed to prevent proteolytic degradation. Nucleic acids are eliminated by treating the samples with $1 \%$ streptomycin sulfate for $15 \mathrm{~min}$, followed by a $10 \mathrm{~min}$ centrifugation $(11,000$

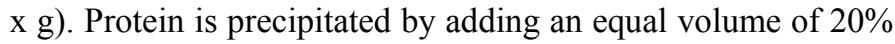
TCA to protein $(0.5 \mathrm{mg})$ and centrifuged for $1 \mathrm{~min}$. The TCA solution is removed and the sample resuspended in $10 \mathrm{mM} 2,4$ dinitrophenylhydrazine (2,4-DNPH) solution. Samples are incubated at room temperature for $15-30 \mathrm{~min}$. $500 \mu \mathrm{l}$ of $20 \%$ TCA is added and samples centrifuged for $3 \mathrm{~min}$. The resultant supernatant is discarded, the pellet washed in ethanol:ethyl acetate and allowed to incubate at room temperature for 10 $\min$. The samples are centrifuged again for $3 \mathrm{~min}$ and the ethanol:ethyl acetate steps are repeated 2 more times. The precipitate is resuspended in $6 \mathrm{M}$ guanidine solution, centrifuged for $3 \mathrm{~min}$ and insoluble debris removed. The maximum absorbance $(360-390 \mathrm{~nm})$ is read versus the appropriate blanks $(2 \mathrm{M} \mathrm{HCl})$ and the carbonyl content calculated using the molar absorption coefficient of $22,000 \mathrm{M}^{-1}$ $\mathrm{cm}^{-1}$.

\section{HNE-Protein Adduct Immunoreactivity}

HNE, a major component of lipid peroxidation, has been shown to react with proteins to form HNE-protein adducts. HNE-protein adducts are relatively stable and can be used as a 
marker of radical-mediated oxidative stress and tissue/cell damage. HNE-protein adduct formation is increased under chronic alcoholism (35). Therefore, it may be helpful to measure HNE-protein adducts under ACA-induced cardiac damage. The formation of reducible HNE-protein adducts (Michael or imine adducts) can be measured using an ELISA method as described (36). Mitochondria are thawed, then diluted to $0.02 \mathrm{mg} / \mathrm{ml}$ in $50 \mathrm{mM}$ phosphate buffer at $\mathrm{pH} 7.4$, and subsequently boiled for $5 \mathrm{~min}$. $50 \mu \mathrm{l}$ of each sample is added to the well of a 96-well microplate, and the protein is allowed to bind for 1 hour at $37^{\circ} \mathrm{C}$. Phosphate buffer is used to rinse the wells, which are then treated with $100 \mu 1$ of $50 \mathrm{mM}$ $\mathrm{NaBH}_{4}$ for another hour at $37^{\circ} \mathrm{C}$ to reduce further HNE-protein adduct formation. The well is blocked for $30 \mathrm{~min}$ and subsequently incubated for 1 hour at $37^{\circ} \mathrm{C}$ with rabbit antibody 672, which recognizes the reduced HNE-protein adduct. The well is washed and incubated with an alkaline phosphataseconjugated goat anti-rabbit antibody (Bio-Rad), and then developed using p-nitropheny1 phosphate (Sigma Chemical, St. Louis, MO).

\section{RESULTS AND DISCUSSION}

The metabolism of ethanol within the body has been investigated and identification of the pathway is useful for the purposes of further investigation. After ethanol is absorbed into the cells, it is converted into ACA by ADH in the cytosol. The ACA that is present is further oxidized into acetate by ALDH within the mitochondrial matrix. Both of these oxidation reactions yield the production of one equivalent NADH (Fig. $1)$.

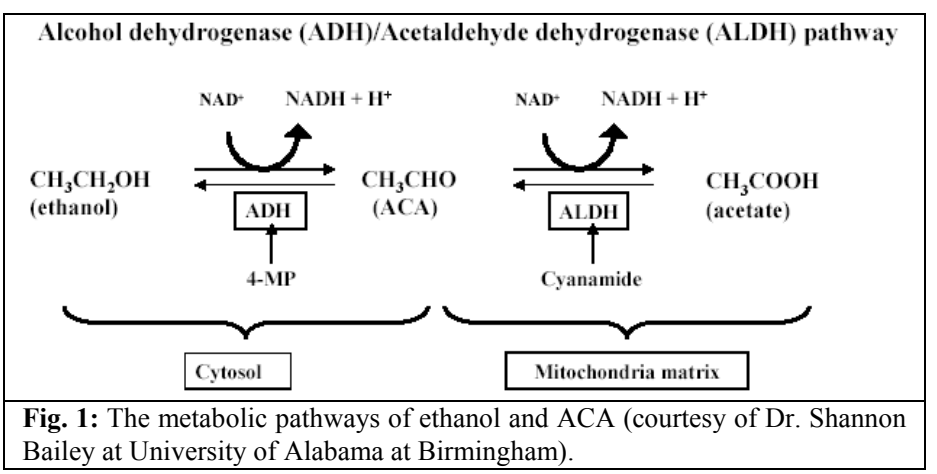

The above pathway results in the production of free radicals predicated upon changes in NADH amounts and NADH/NAD ${ }^{+}$ redox ratios (37). These increases alter the activity of xanthine oxidase, which generates free radicals. Another pathway of ethanol metabolism is the microsomal ethanol oxidizing system (MEOS), which catalyzes the conversion of ethanol to ACA. In chronic situations, it has been shown that the metabolism of ethanol shifts from the ADH pathway, to one involving the MEOS, and CYP2E1 (38). In the chronic state, the levels of MEOS and CYP2E1 have been shown to be elevated (39). The activation of CYP2E1 by ethanol is one of the main metabolic pathways for ethanol which is responsible for the production of oxidative damage in hepatocytes (40). Also, CYP2E1 is expressed constitutively in isolated rat cardiomyocytes (41). Increased lipid peroxidation and CYP2E1 levels have been observed following chronic ethanol administration. This is consistent with the finding that enhanced lipid peroxidation following ethanol ingestion may be prevented with the use of CYP2E1 inhibitors (42). In addition, ethanol may also lead to oxidative insults via a reaction involving aldehyde oxidase with ACA or NADH, which can dysregulate mitochondrial oxidative metabolism (36). The electron transport chain within the mitochondria contributes significantly to the production of reactive oxygen species (ROS), and exposure of ethanol augments the ROS production, which may further be exacerbated by a decrease in mitochondrial antioxidant defenses (43).

For the purposes of investigating the effects of ethanol and ACA, there are several inhibitors that may be employed. Two such inhibitors that may be utilized in investigation are 4methylpyrazole (4-MP), a selective ADH inhibitor (44), and an ALDH inhibitor, cyanamide (21). Diallyl sulfide, a CYP2E1 inhibitor, may be useful for the assessment of ethanol/ACA (40). As previously mentioned, aldehyde oxidase and xanthine oxidase are both involved in the metabolism of ethanol and ACA, and result in oxidative stress leading to cardiac mechanical dysfunction. As indicated in Fig. 2, both aldehyde oxidase and xanthine oxidase may be intervened pharmacologically with menadione and allopurinol, respectively.

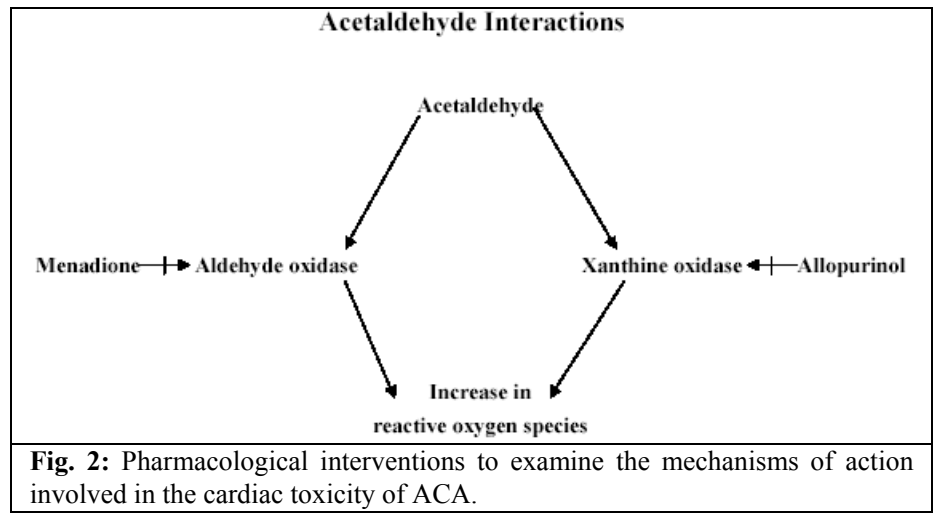

One of the main benefits of the in vitro myocyte culture method is that the effect of ACA on cardiac excitationcontraction coupling may be examined with the assistance of specific pharmacological interventions for ACA metabolism. The aforementioned inhibitors of the ethanol/ACA metabolic pathway or sources of free radical generation may be added to the culture dishes instead of employing chronic feeding regimen for in vivo analysis. Another advantage is the ease with which drug interactions may be studied. People with alcohol abuse often use or abuse other drugs that may affect the pharmacokinetics of ethanol, for example, it is reported that 
$30-60 \%$ of alcoholics consume cocaine (45). Despite the evidence of multiple usage of drugs is involved along with alcohol consumption, little research has been done to understand the drug interactions. Another example for drug interaction is the combinatorial effects of nicotine (smoking) and alcohol. Ethanol and nicotine may synergistically increase heart rate (46), although the mechanism of action remains to be elucidated. The use of specific inhibitors in an in vitro experimental setting (such as the one described in this manuscript) should be able to provide valuable information regarding the combined effects and interactions of other drugs associated with alcohol usage. Development of an in vitro method regarding the use of ACA allows these interactions to be studied in a reliable manner that does not involve a timeconsuming in vivo feeding regimen. In addition, parameters such as interstitial materials, nerve fibers, and other cells, which are often present in the setting of in vivo should be eliminated using the in vitro culture method. The presence of heterogeneous cell types, such as fibroblasts, and nerve terminals that occur in multicellular preparations like papillary muscles can make experimental results difficult or impossible to interpret. The mechanical function of the myocytes may be affected by non-myocyte components such as the coronary vasculature and/or interstitial connective tissue. For example, it is possible that the modulations in the contractile performance under ethanol exposure may not be due to actual reduced function of the myocyte, but rather due to increased interstitial fibrosis. Therefore, it is necessary that there are methods available for scientists to study the smallest cardiac contractile unit - ventricular myocytes specifically, independent of any surrounding factors. However, there are drawbacks to this cell culture model as with all the in vitro study, e.g., lack of the physiologic environment which would otherwise be present in an in vivo setting. In response to this deficit, the aforementioned ADH and ALDH transgenic models should be useful for interpretation of the cardiac effects of ACA, in conjunction with our in vitro cell culture model.

\section{Synopsis}

Alcohol abuse continues to remain as a prevalent social problem contributing to severe heart problems in alcoholics. It is a current opinion that the toxic effects of alcohol on the heart are attributable, in large part, to the first metabolic product of ethanol - ACA. ACA is formed from the breakdown of ethanol in cells and is far more toxic and reactive than ethanol. In order to better understand the adverse repercussions of chronic alcohol abuse, assessment of cardiac toxicity of ACA using our described methods should lead to useful clues regarding the pathogenesis of alcoholic cardiomyopathy.

\section{ACKNOWLEDGMENTS}

The authors would like to acknowledge Dr. Matthew Picklo, Sr. from University of North Dakota School of Medicine and
Dr. Amy Davidoff from University of New England for their generous help in developing the experimental protocols. Research in Dr. Ren's laboratory described in this manuscript has been supported by grants from University of North Dakota New Faculty Award, North Dakota Experimental Program to Stimulate Competitive Research (EPSCoR), the NASA NCC582 (University of North Dakota) and National Institute of Health (NIAAA) 1R15AA/HL13575-01.

\section{REFERENCES}

1. Fernandez-Sola J, Estruch R, Grau JM, Pare JC, Rubin E, Urbano-Marquez A. The relation of alcoholic myopathy to cardiomyopathy. Ann Intl Med 1994; 120:529-536.

2. Patel VB, Why HJ, Richardson PJ, Preedy VR. The effects of alcohol on the heart. Adverse Drug React Toxicol Rev 1997; 16:15-43.

3. Richardson PJ, Patel VB, Preedy VR. Alcohol and the myocardium. Novartis Found Symp 1998; 216:35-45.

4. Preedy VR, Patel VB, Reilly ME, Richardson PJ, Falkous G, Mantle D. Oxidants, antioxidants and alcohol: implications for skeletal and cardiac muscle. Front Biosci 1999; 4:e58-66.

5. Laposata EA, Lange LG. Presence of nonoxidative ethanol metabolism in human organs commonly damaged by ethanol abuse. Science 1986; 231:497-499.

6. Espinet C, Argiles JM. Ethanol and acetaldehyde levels in rat blood and tissues after an acute ethanol administration. IRCS Med Sci 1984; 12:830-831.

7. Ren J, Davidoff AJ, Brown RA. Acetaldehyde depresses shortening and intracellular $\mathrm{Ca}^{2+}$ transients in adult rat ventricular myocytes. Cell Mol Biol 1997; 43: 825-834.

8. Brown RA, Jefferson L, Sudan N, Lloyd LC, Ren J. Acetaldehyde depresses myocardial contraction and cardiac myocyte shortening in spontaneously hypertensive rats: Role of intracellular $\mathrm{Ca}^{2+}$. Cell Mol Biol 1999; 45:453-465.

9. Ren J, Wold LE, Epstein PN. Diabetes enhances acetaldehyde-induced depression of cardiac myocyte contraction. Biochem Biophys Res Comm 2000; 269:697703.

10. Ren J, Brown RA. Influence of chronic alcohol ingestion on acetaldehyde-induced depression of cardiac contractile function. Alcohol Alcoholism 2000; 35:554-560.

11. Leiber C, Barona E, Leo M, Garro A. Effect of chronic alcohol consumption on the metabolism of ethanol. Prog Clin Biochem Res 1987; 241:161-172.

12. Yoshida A. Molecular genetics of human aldehyde dehydrogenase. Pharmacogenetics 1992; 2:139-147.

13. Preedy VR, Richardson PJ. Ethanol induced cardiovascular disease. Br Med Bull 1994; 50:152-163.

14. Brown RA, Crawford M, Natavio M, Petrovski P, Ren J. Dietary magnesium supplementation attenuates ethanolinduced myocardial dysfunction. Alcohol Clin Exp Res 1998; 22:2062-2072.

15. De Carli LM, Leiber CS. Fatty liver in the rat after prolonged intake of ethanol with a nutritionally adequate new liquid diet. $J$ Nutrit 1967; 91:331-336. 
16. Keane B, Leonard BE. Rodent models of alcoholism: a review. Alcohol and Alcohol 1989; 24:299-309.

17. Edenberg HJ, Zhang K, Fong K, Bosron WF, Li TK. Cloning and sequencing of cDNA encoding the complete mouse liver alcohol dehydrogenase. Proc Natl Acad Sci USA 1985; 82:2262-2266.

18. Taketo M, Schroeder AC, Mobraaten LE et al. FVB/N: an inbred mouse strain preferable for transgenic analyses. Proc Natl Acad Sci USA 1991; 88:2065-2069.

19. Overbeek PA, Aguilar-Cordova E, Hanten G. Coinjection strategy for visual identification of transgenic mice. Transgenic Res 1991; 1:31-37.

20. Liang Q, Carlson EC, Borgerding AJ, Epstein PN. A transgenic model of acetaldehyde overproduction accelerates alcohol cardiomyopathy. J Pharmacol Exp Ther 1999; 291: 766-772.

21. Duan J, McFadden GE, Borgerding AJ, Norby FL, Ren BH, Ye G, Epstein PN, Ren J. Overexpression of alcohol dehydrogenase exacerbates ethanol-induced contractile defect in cardiac myocytes. Am J Physiol Heart Circ Physiol 2002; 282: H1216-H1222.

22. Ellingsen O, Davidoff AJ, Prasad SK, Berger HJ, Springhorn JP, Marsh JD, Kelly RA, Smith TW. Adult rat ventricular myocytes cultured in defined medium: phenotype and electromechanical function. Am J Physiol 1993; 265:H747-H754.

23. Aberle NS II Ren J. Acetaldehyde depresses cardiac contraction in ventricular myocytes: Role of cytochrome p-450 oxidase, xanthine oxidase and lipid peroxidation. Alcohol Clin Exp Res 2003, in press.

24. Ren J, Wold L. Measurement of cardiac mechanical function in isolated ventricular myocytes from rats and mice by computerized video-based imaging. Biol Proced Online 2001; 3:43-53.

25. Yao A, Su Z, Nonaka A, Zubair I, Lu L, Philipson KD, Bridge JHB, Barry WH. Effects of overexpression of the $\mathrm{Na}^{+}-\mathrm{Ca}^{2+}$ exchanger on $\left[\mathrm{Ca}^{2+}\right]_{\mathrm{i}}$ transients in murine ventricular myocytes. Circ Res 1998; 82:657-665.

26. McCall E, Ginsburg KS, Bassani RA, Shannon TR, Qi M, Samarel AM, Bers DM. Ca flux, contractility and excitation-contraction coupling in hypertrophic rat ventricular myocytes. Am J Physiol 1998; 274:H1348H1360.

27. Bers DM. Calcium fluxes involved in control of cardiac myocyte contraction. Circ Res 1996; 87:275-281.

28. Ide T, Tsutsui H, Hayashidani S. Mitochondrial DNA damage and dysfunction associated with oxidative stress in failing hearts following myocardial infarction. Circ Res 2001; 88:529-535.

29. Picklo MJ, Amarnath V, McIntyre JO, Graham DG, Montine TJ. 4-Hydroxy-2(E)-nonenal inhibits CNS mitochondrial respiration at multiple sites. $J$ Neurochem 1999; 72:1617-1624.

30. Picklo MJ Sr., Montine TJ. Acrolein inhits respiration in isolated brain mitochondria. Biochim Biophys Acta 2001; 1535:145-152.

31. Griffith OW. Glutathione and glutathione disulfide In: Bergmeyer HU Bergmeyer J (eds) Methods of enzymatic analysis Vol 8, Verlag Chemie Deerfield Beach, FL. 1986; pp. 521-529.

32. Ye G, Metreveli NS, Ren J, Epstein PN. Overexpression of metallothionein reverses diabetes induced functional deficits in diabetic cardiomyocytes by inhibiting ROS production. Diabetes 2003, in press.

33. Esterbauer H, Schaur RJ, Zollner H. Chemistry and biochemistry of 4-hydroxynonenal malonaldehyde and related aldehydes. Free Radic Biol Med 1991; 11: 81-128.

34. Ren J, Roughead ZK, Norby FL, Rakoczy S, Wold LE, Mabey RL, Brown-Borg HM. Increases in insulin-like growth factor-1 level and peroxidative damage after gestational ethanol exposure in rats. Pharmacol Res 2003, in press.

35. Ohhira M, Ohtake T, Matsumoto A, Saito H, Ikuta K, Fujimoto Y, Ono M, Toyokuni S, Kohgo Y. Immunohistochemical detection of 4-hydroxy-2-nonenalmodified-protein adducts in human alcoholic liver diseases. Alcohol Clin Exp Res 1998; 22:145S-149S.

36. Montine KS, Reich E, Neely MD, Sidell KR, Olson SJ, Markesbery WR, Montine TJ. Distribution of reducible 4hydroxynonenal adduct immunoreactivity in Alzheimer disease is associated with APOE genotype. J Neuropathol Exp Neurol 1998; 57:415-425.

37. Mantle D, Preedy VR. Free radicals as mediators of alcohol toxicity. Adverse Drug React Toxicol Rev 1999; 18:235-252.

38. Tanaka E, Terada M, Misawa S. Cytochrome P450 2E1: its clinical and toxicological role. J Clin Pharm Ther 2000; 25:165-175.

39. Lieber CS. Alcoholic liver injury: pathogenesis and therapy in 2001. Pathol Biol (Paris) 2001; 49:738-752.

40. Cederbaum AI, Wu D, Mari M, Bai J. CYP2E1-dependent toxicity and oxidative stress in HepG2 cells. Free Radic Biol Med 2001; 31:1539-1543.

41. Thum T, Borlak J. Cytochrome P450 mono-oxygenase gene expression and protein activity in cultures of adult cardiomyocytes of the rat. Br J Pharmacol 2000; 130: 1745-1752.

42. Novak RF, Woodcroft KJ. The alcohol-inducible form of cytochrome P450 (CYP 2E1): role in toxicology and regulation of expression. Arch Pharm Res 2000; 23: 267282.

43. Hoek JB, Cahill A, Pastorino JG. Alcohol and mitochondria: A dysfunctional relationship. Gastroenterology 2002; 122:2049-2063.

44. Sarkola T, Iles MR, Kohlenberg-Mueller K, Eriksson CJ. Ethanol acetaldehyde, acetate and lactate levels after alcohol intake in white men and women: effect of 4methylpyrazole. Alcohol Clin Exp Res 2002; 26:239-245.

45. Petry NM. A behavioral economic analysis of polydrug abuse in alcoholics: asymmetrical substitution of alcohol and cocaine. Drug Alcohol Depend 2001; 62:31-39.

46. Mehta MC, Jain AC, Billie M. Combined effects of alcohol and nicotine on cardiovascular performance in a canine model. J Cardiovasc Pharmacol 1998; 31:930-936. 


\section{PROTOCOLS}

Protocols for isolation of ventricular myocytes and measurement of myocyte mechanics has been described in detail in our previously published article as the following: Ren J, Wold LE. Measurement of cardiac mechanical function in isolated ventricular myocytes from rats and mice by computerized video-based imaging. Biol Proced Online 3: 43-53, 2001. Please refer for detail. The following lists additional protocols described in this manuscript.

\section{Evaluation of the Function of Sarco(endo)plasmic Reticulum $\mathrm{Ca}^{2+}$-ATPase (SERCA)}

1. Make the fluo-3AM stock solution as follows:

- $\quad 5 \mu \mathrm{l} 1 \mathrm{M}$ fluo stock

- $1 \mu \mathrm{l}$ pluronic solution

- $5 \mathrm{ml}$ contractile buffer (from the stock below)

- $0.05 \mathrm{~g}$ Albumin

2. Prepare the following perfusates:

$\begin{array}{ll}\text { Contractile buffer } & 300 \mathrm{ml} \mathrm{HEPES} \\ & 0.54 \mathrm{~g} \text { Glucose } \\ & 300 \mu 1 \mathrm{M} \mathrm{CaCl} \mathrm{M}_{2} \\ 0 \mathrm{Ca}^{2+} \text { buffer } & 50 \mathrm{ml} \mathrm{HEPES} \\ & 0.09 \mathrm{~g} \text { Glucose } \\ \text { Lithium buffer no } \mathrm{Ca}^{2+} & 50 \mathrm{ml} \text { Lithium stock } \\ & 0.09 \mathrm{~g} \text { Glucose } \\ \text { Lithium buffer }+\mathrm{Caff} & 10 \mathrm{ml} \text { Lithium stock } \\ & 0.018 \mathrm{~g} \text { Glucose } \\ & 0.019 \mathrm{~g} \text { Caffeine }\end{array}$

3. Fill the four chambers with the above solutions and remove all air bubbles in the tubing.

4. Load a plate of cells with fluo-3AM by removing the contractile buffer and replacing with fluo-3AM. Load for 30 minutes. After loading, wash the cells 2-3 times with contractile buffer.

5. Isolate a cell in the viewer and make sure that the electrically stimulated (ES) fluo trace has little background noise.

6. Record four ES fluo traces.

7. Switch the perfusate to the $\mathrm{Ca}^{2+}$-buffer and allow perfusion for 15 seconds. Once the cell stops contracting, turn off the electrical stimulus (ES).

8. Switch the perfusate to Lithium buffer with $0 \mathrm{Ca}^{2+}$ and perfuse for 15 seconds. (No ES).

9. Once the program begins recording, perfuse the cell with a $100 \mathrm{msec}$ puff of the Lithium buffer plus caffeine.

10. Wash the cells with contractile buffer for 1-2 minutes before finding another cell on the same plate.

11. Record 5-6 traces per well.

\section{Evaluation of $\mathrm{Na}^{+} / \mathrm{Ca}^{2+}$ Exchanger (NCX) Function}

1. Make the fluo-3AM stock solution as follows:

- $5 \mu \mathrm{l} 1 \mathrm{M}$ fluo stock

- $1 \mu \mathrm{l}$ pluronic solution

- $5 \mathrm{ml}$ contractile buffer (from the stock below)

- $0.05 \mathrm{~g}$ Albumin

2. Prepare the following perfusates: 


\begin{tabular}{|c|c|}
\hline Contractile buffer (4) & $200 \mathrm{ml}$ HEPES \\
\hline & $0.36 \mathrm{~g}$ Glucose \\
\hline & $200 \mu 11 \mathrm{M} \mathrm{CaCl}_{2}$ \\
\hline Contractile + Caff (1) & $\begin{array}{l}10 \mathrm{ml} \text { contractile buffer } \\
0.019 \mathrm{~g} \text { Caffeine }\end{array}$ \\
\hline Contractile $+\mathrm{Ni}(\mathbf{3})$ & $\begin{array}{l}50 \mathrm{ml} \text { contractile buffer } \\
250 \mathrm{ul} 1 \mathrm{M} \mathrm{NiCl} \text {. }\end{array}$ \\
\hline Contractile + Caff $+\mathrm{Ni}(\mathbf{2})$ & $\begin{array}{l}10 \mathrm{ml} \text { contractile buffer } \\
0.019 \mathrm{~g} \mathrm{Caffeine} \\
50 \mu \mathrm{1} \mathrm{M} \mathrm{NiCl}_{2}\end{array}$ \\
\hline
\end{tabular}

3. Fill the four chambers with the above solutions and remove all air bubbles in the tubing.

4. Load a plate of cells with fluo-3AM by removing the contractile buffer and replacing with fluo-3AM. Load for 30 minutes. After loading, wash the cells 2-3 times with contractile buffer.

5. Isolate a cell in the viewer and make sure that the electrically stimulated (ES) fluo trace has little background noise.

6. Record four ES fluo traces.

7. Turn the ES off for 30 seconds.

8. Perfuse the cell with contractile buffer plus caffeine for 6 seconds. Once the fluo trace returns to baseline, perfuse with contractile buffer.

9. Allow the cell to recover for 1-2 minutes. Try recording a baseline fluo-3 trace to see if the background is noisy.

10. Record four ES fluo traces (on the same cell as before).

11. Switch the perfusate to contractile buffer plus nickel for 15 seconds. Once the cell stops twitching, turn the ES off.

12. Switch the perfusate to contractile buffer plus nickel plus caffeine and perfuse for 6 seconds.

13. Wash the plate of cells for 1-2 minutes before finding another one. The protocol can be repeated 4-5 times on the same well of cells.

\section{Oxidative Stress Status - Glutathione Assay}

\section{Preparing samples}

- Measure out about 0.050 grams of frozen tissue. Put the sample in a clearly labeled $1 \mathrm{ml}$ micro-centrifuge tube. Keep all tubes on ice at all times.

- Take the weight of the sample and multiply it by 4000 .

- This is the amount in $\mu$ l of picric acid you should add to each tube.

- $\quad$ Sonicate each tube for 5-15 seconds.

- Centrifuge each tube at 13,500 rpm for 20 minutes.

- Take off the supernatant and place it in another clearly labeled tube.

- $\quad$ These samples can be frozen in the $-80^{\circ} \mathrm{C}$ freezer until a later time.

\section{Assay Procedures}

Figure out how many cuvettes you will need to do your samples in triplicate, twice. One for GSH and another for GSSG. This will give you how much buffer you will need to do the assay to avoid wasting reagents.

Example: $\quad$ NADPH $\quad 150$ samples X $0.350 \mathrm{ml}=52.5 \mathrm{ml}$ of buffer needed.

DTNB $\quad 150$ samples X $\quad 0.05 \mathrm{ml}=7.5 \mathrm{ml}$ of buffer needed.

GR $\quad 150$ samples $X \quad 0.025 \mathrm{ml}=3.75 \mathrm{ml}$ of buffer needed.

Be sure to round up number of samples and account for extra ml needed to calculate the standard curve.

\section{Buffers}

- $\quad 125 \mathrm{mM}$ Phosphate/EDTA buffer:

Mono (500ml): $0.125 \mathrm{M} \mathrm{X} \mathrm{0.5L} \mathrm{X} \mathrm{138.0(F.W.)}=8.625 \mathrm{~g}$

Di (500ml): $0.125 \mathrm{M} \mathrm{X} \mathrm{0.5L} \mathrm{X} \mathrm{142.0(F.W.)}=8.875 \mathrm{~g}$ 
- $\quad$ EDTA buffer: $(500 \mathrm{ml})$

$0.0063 \mathrm{M}$ X $0.5 \mathrm{~L}$ X $372.24(\mathrm{~F} . \mathrm{W})=.1.173 \mathrm{~g}$

- $\quad$ Add 1.173 of EDTA buffer to the mono buffer and another $1.173 \mathrm{~g}$ to the di buffer.

Stir each solution for 25-30 minutes.

Pour $500-600 \mathrm{~mL}$ of the di buffer into a $1000 \mathrm{~mL}$ beaker. Add the mono buffer to the di buffer until the $\mathrm{pH}$ of the combined buffers is 7.5. Pour buffer into bottle labeled Phosphate/EDTA.

- $\quad 0.3 \mathrm{mM}$ NADPH buffer: $(350 \mu \mathrm{l})$

0.0003M X liters of buffer needed calculated above (ex. 0.0525L) X 833(F.W.) = number of grams.

- $6 \mathrm{mM}$ DTNB buffer: $(50 \mu \mathrm{l})$

0.006M X liters of buffer needed calculated above (ex. 0.0075L) X 396.4(F.W.) = number of grams.

- Add the number of grams of NADPH and the number of grams of DTNB to the amount of Phosphate/EDTA buffer needed which was calculated in the example. Put this in a jar or a container which can be kept cold and in the dark. This will be the mix buffer.

- GR Each time you open up a new lot number or sample the dilution will be different.

2500 unit $=1: 50$ dilution. $3.75 \mathrm{ml} / 50=75 \mu \mathrm{l} \mathrm{GR}$ in $3.765 \mathrm{ml}$ mix buffer

500 unit $=1: 10$ dilution. $3.75 \mathrm{ml} / 10=375 \mu \mathrm{l} \mathrm{GR}$ in $3.375 \mathrm{ml}$ mix buffer

600 unit $=1: 200$ dilution. $3.75 \mathrm{ml} / 200=18.75 \mu \mathrm{lin} 3.731 \mathrm{ml}$ mix buffer

Place the solution in a small falcon tube that should be kept cold.

\section{Standard Curve Mix}

GSH: start with $10 \mathrm{mM}$ stock $=0.0030703 \mathrm{~g}$ in $1 \mathrm{~mL} \mathrm{H}_{2} \mathrm{O}$

$1 \mathrm{mM}=100 \mu \mathrm{l}$ of $10 \mathrm{mM}$ in $900 \mu \mathrm{H}_{2} \mathrm{O}$

$0.1 \mathrm{mM}=100 \mu \mathrm{l}$ of $1 \mathrm{mM}$ in $900 \mu \mathrm{H} \mathrm{H}_{2} \mathrm{O}$

$0.01 \mathrm{mM}=100 \mu \mathrm{l}$ of $0.1 \mathrm{mM}$ in $900 \mu \mathrm{H} \mathrm{H}_{2} \mathrm{O}$

$0.002 \mathrm{mM}=10 \mu \mathrm{l}$ of $0.01 \mathrm{mM}$ in $40 \mu \mathrm{H} \mathrm{H}_{2} \mathrm{O}$

- $\quad$ be sure to change tips of pipette between each addition and mix each solution

Conditions: The system is run at $30^{\circ} \mathrm{C}$. Run for 5 minutes. Read at $412 \mathrm{~nm}$.

\section{Standard Curve}

Table 1:

\begin{tabular}{|c|c|c|c|c|c|}
\hline \multicolumn{2}{|c|}{ Mix Buffer } & \multicolumn{2}{|l|}{$\mathrm{H}_{2} \mathrm{O}$} & \multirow{2}{*}{$\begin{array}{l}\text { GSH } \\
5 \mu \mathrm{l} \\
\end{array}$} & \multirow{2}{*}{$\begin{array}{l}\mathbf{G R} \\
25 \mu \mathrm{l}\end{array}$} \\
\hline 400ul & $200 \mathrm{mM}$ & $70 \mu \mathrm{l}$ & & & \\
\hline & $0.01 \mathrm{mM}$ & $\begin{array}{l}70 \mu l \\
65 \\
55 \\
45 \\
35 \\
25 \\
\end{array}$ & $\begin{array}{l}5 \mu l \\
10 \\
20 \\
30 \\
40 \\
50 \\
\end{array}$ & & \\
\hline & $0.1 \mathrm{mM}$ & $\begin{array}{l}70 \mu l \\
65\end{array}$ & $\begin{array}{l}5 \mu l \\
10\end{array}$ & & \\
\hline \multicolumn{6}{|l|}{ Blank } \\
\hline $400 \mu \mathrm{l}$ & & $75 \mu \mathrm{l}$ & $0 \mu \mathrm{l}$ & & \\
\hline
\end{tabular}


Figure standard curve on the computer template (Cricket Graph). Take the Blank and subtract from all the standards and graph a curve. The curve must be linear to continue on to the sample. ( 0.990 or better)

\section{Samples}

Table 2:

Mix buffer

400ul

$\begin{array}{lll}\mathrm{H}_{2} \mathrm{O} & \text { Sample } & \text { GR } \\ 70 \mu \mathrm{l} & 5 \mu \mathrm{l} & 25 \mu \mathrm{l}\end{array}$

Add the GR last because this is what starts the reaction.

If the count is higher or lower than the top or bottom of the curve, you must adjust your sample to get it within the curve.

\section{6. $G S S G$}

This is run after GSH and is done by adding Vinyl Pyridine to each of the samples. ( $1 \mu \mathrm{l}$ of VP to $50 \mu \mathrm{l}$ of sample, vortex and let sit for 1 hour in fridge before you run on spec.) Run the samples the same as you ran the GSH samples.

\section{Table 3:}

Mix

$400 \mu 1$
$\mathrm{H}_{2} \mathrm{O}$
$70 \mu \mathrm{l}$
VP sample

$5 \mu \mathrm{l}$
GR

$25 \mu 1$

\section{Protein Carbonyl Assay}

1. A $200 \mathrm{mg}$ tissue sample is finely minced in $3 \mathrm{ml}$ of Lysis buffer and is incubated at room temperature for $15 \mathrm{~min}$. The supernatant is then transferred to an Eppendorf tube and centrifuged at 6,000 x g for $10 \mathrm{~min}$. Pellet is left behind.

2. Two tubes of samples are prepared for each extracted protein with $500 \mu \mathrm{l}$ in each tube. $500 \mu \mathrm{l}$ of $20 \%$ TCA is added to each tube to precipitate the protein. Samples are incubated on ice for $10 \mathrm{~min}$ and centrifuged at $11,000 \mathrm{x} \mathrm{g}$ for $5 \mathrm{~min}$ using a table top centrifuge.

3. Discard supernatant and add $500 \mu \mathrm{l} 2 \mathrm{M} \mathrm{HCl}$ to one tube (serves as blank for that sample) and add $500 \mu 10 \mathrm{mM} \mathrm{2,4,} \mathrm{DNPH}$ (dinitrophenylhydrazine, dissolved $2.5 \mathrm{M} \mathrm{HCl}$ ) to the other tube.

4. Incubate the tubes in the dark for 1 hour, with vortexing every $15 \mathrm{~min}$.

5. At the end of 1 hour, add $500 \mu \mathrm{l} 20 \%$ TCA to each tube and centrifuge $11,000 \times \mathrm{g}$ for $3 \mathrm{~min}$ at room temperature.

6. Remove supernatant and wash pellet with Ethanol/Ethyl acetate wash (1:1) incubate for $10 \mathrm{~min}$. Then centrifuge $11,000 \mathrm{~g}$ for 3 min at room temperature, repeat 2 more times to wash pellet.

7. After the last wash, add $600 \mu \mathrm{l} 6 \mathrm{M}$ Guanadine $\mathrm{HCl}$ to pellet and incubate at $37^{\circ} \mathrm{C}$ for $30-60 \mathrm{~min}$ to dissolve pellet, centrifuge $11,000 \mathrm{x} \mathrm{g}$ for $1 \mathrm{~min}$ to remove insoluble debris.

8. Read the clear supernatant at $360 \mathrm{~nm}$ (spectrophotometer may be set to scan $360-390 \mathrm{~nm}$ wavelength).

9. Bradford the final sample blanks (usually 1:200 dilution). Use the $6 \mathrm{M}$ Guanadine $\mathrm{HCl}$ for standard with the BSA solution.

10. The final protein carbonyl content $=$ Absorption at $360 \mathrm{~nm} \mathrm{X} 45.45 \mathrm{nmol} / \mathrm{ml} /$ protein content $(\mathrm{mg})$. 